\title{
Monitoring of Gyps species vulture in Nawalparasi district, Nepal
}

\begin{abstract}
P. Subedi ${ }^{1}$
Critically endangered White-rumped vulture (WRV), Gyps bengalensis and Slender-billed vulture (SBV), Gyps tenuirostris monitoring was conducted in Nawalparasi district in the winter of 2005 following Postupalsky criterion. The objectives of this study were to identify and monitor nest localities, behaviour and to explore information about the vultures. A total of 48 Gyps vulture nest was located at six colonies. Of these nests, 18 were found to be active nets, six nests belonged to SBV and 12 nests belonged to WRV. Hundred percent nestling successes were observed in the study area. Restricted pesticides i.e. $\mathrm{BHC}$ and DDT were found used in this area. Diclofenac was the commonly used veterinary drug in the treatment of livestock. Carcasses disposal practice was found favorable to the vulture's survival. Gyps vulture richness found in this area is due to the availability of food i.e. floating carcass along the edge of the Narayani river and suitable habitat for roosting and nesting. The majority of the respondents had found favorable attitude towards vulture conservation. Further studies on Gyps vulture to identify the breeding status, head droppings behavior as well as conservation awareness program for local people and school children are recommended for long-term survival of these lords of the sky in the study area.
\end{abstract}

Key words: Gyps vulture, monitoring, diclofenac, pesticides

$\mathbf{V}$ ultures are the largest flying raptors in Nepal. Vultures along with hawks, kite, baza, buzzard, eagle, harrier, and osprey represent the avian family Accipitridae. These birds of prey are a major component of order Falconiformes. Out of the nine species of vultures are found in South Asia, eight species (Table 1) are reported in Nepal. Two species, White-rumped vulture (WRV), Gyps bengalensis, and Slender-billed vulture (SBV), Gyps tenuirostris, were formerly distributed in many parts of Nepal (e.g. Grimmett et. al. 2000, Inskipp and Inskipp 1991) and the Indian vulture (INV) or the Long-billed Vulture Gyps indicus may occur in Nepal but there is no confirmed record yet (Giri and Baral 2001) are now listed as Critically Endangered on the IUCN RED List (BirdLife International 2006).

Globally, WRV and SBV (here after both referred as Gyps vulture) are found in Nepal, India, Bangladesh, Myanmar, Cambodia and Laos. Additionally, WRV also occurs in Pakistan, Bhutan and Thailand and has been extinct from southern China (Birdlife International 2000).

The WRV was once described as the most common species of vulture found in Indian Sub-continent (Oaks et al. 2004, BirdLife International 2000, Grimmett et al. 1998, Inskipp and Inskipp 1991, Ali and Ripley 1989, Fleming et al. 1976 and Ali and Ripley 1968). This vulture retained strongholds in India and Pakistan and disappeared from most of Southeast Asia in the early $20^{\text {th }}$ Century. A bulk population decline of more than $95 \%$ of this species was first noted at Keoladeo National Park, India in the 1990's. Since then, the catastrophic declines, also involving INV and SBV (split into two sub-species viz: Gyps indicus and Gyps tenuirostris-Rasmussen and Parry 2001) have been continuously reported across the subcontinent (Quoted in Oaks et al. 2004). Current evidence suggests that populations of these species continue to fall very rapidly (Gilbert 2004).

\footnotetext{
${ }^{1}$ Assistant Forest Officer, District Forest Office Kaski, Email: poorneshwor@yahoo.com
} 
Table 1: Status of Vultures Reported in Nepal

\begin{tabular}{|c|c|c|c|c|c|c|c|}
\hline \multirow[b]{2}{*}{ S.N. } & \multirow[b]{2}{*}{$\begin{array}{l}\text { Scientific } \\
\text { Name }\end{array}$} & \multirow[b]{2}{*}{$\begin{array}{l}\text { English } \\
\text { Name }\end{array}$} & \multirow[b]{2}{*}{$\begin{array}{l}\text { Nepali } \\
\text { Name }\end{array}$} & \multicolumn{4}{|c|}{ Status } \\
\hline & & & & $\begin{array}{l}\text { BirdLife/ } \\
\text { IUCN }\end{array}$ & $\begin{array}{c}\text { CITES } \\
\text { Appendix }\end{array}$ & Nepal & Breeding \\
\hline 1 & Gyps bengalensis & $\begin{array}{l}\text { White-rumped } \\
\text { vulture }\end{array}$ & $\begin{array}{l}\text { Dangar } \\
\text { giddha }\end{array}$ & $\begin{array}{l}\text { Critically } \\
\text { endangered }\end{array}$ & II & $\begin{array}{l}\text { Nationally } \\
\text { threatened }\end{array}$ & Resident \\
\hline 2 & Gyps tenuirostris & $\begin{array}{l}\text { Slender-billed } \\
\text { vulture }\end{array}$ & $\begin{array}{l}\text { Sano khairo } \\
\text { giddha }\end{array}$ & $\begin{array}{l}\text { Critically } \\
\text { endangered }\end{array}$ & II & $\begin{array}{l}\text { Nationally } \\
\text { threatened }\end{array}$ & Resident \\
\hline 3 & $\begin{array}{l}\text { Gyps } \\
\text { bimalayensis }\end{array}$ & $\begin{array}{l}\text { Himalayan } \\
\text { Griffon }\end{array}$ & $\begin{array}{l}\text { Himali } \\
\text { giddha }\end{array}$ & Common & II & - & Resident \\
\hline 4 & Gyps Gyps fulvus & $\begin{array}{l}\text { Eurasian } \\
\text { Griffon }\end{array}$ & $\begin{array}{l}\text { Khairo } \\
\text { giddha }\end{array}$ & Common & II & - & $\begin{array}{l}\text { Passage } \\
\text { migrant, } \\
\text { rare, winter } \\
\text { visitor }\end{array}$ \\
\hline 5 & $\begin{array}{l}\text { Aegypinus } \\
\text { monachus }\end{array}$ & $\begin{array}{l}\text { Cinereous } \\
\text { vulture }\end{array}$ & Raj giddha & $\begin{array}{l}\text { Near } \\
\text { threatened }\end{array}$ & II & $\begin{array}{l}\text { Nationally } \\
\text { threatened }\end{array}$ & $\begin{array}{l}\text { Winter } \\
\text { visitor }\end{array}$ \\
\hline 6 & Sarcogyps calvus & $\begin{array}{l}\text { Red headed } \\
\text { vulture }\end{array}$ & Sun giddha & $\begin{array}{l}\text { Critically } \\
\text { endangered }\end{array}$ & II & $\begin{array}{l}\text { Nationally } \\
\text { threatened }\end{array}$ & Resident \\
\hline 7 & $\begin{array}{l}\text { Neophron } \\
\text { percnopterus }\end{array}$ & $\begin{array}{l}\text { Egyptian } \\
\text { vulture }\end{array}$ & Seto giddha & Endangered & II & - & Resident \\
\hline 8 & Gypaetus barbtus & Lammergeier & Hadphor & Common & II & - & Resident \\
\hline
\end{tabular}

Source: Grimmett et al. 2000 , BirdLife International/IUCN 2006, CITES 2008, Baral H.S. and Inskipp C. 2004.

Once both commonest and resident before 1990's in Nepal, the Gyps vultures have been declining alarmingly. The rate of decline was reported as more than $95 \%$ within last 15 years; however, the current rate of annual decline is nearly $40 \%$ (Baral 2006). It was also reported that besides these two vultures, the remaining other six species of vultures are also declining gradually in Nepal (Baral and Gautam 2007).

The vulture study conducted at different times and places in Nepal such as Kathmandu valley (Giri 1996 and Panthi 1996), Chitwan National park (Giri and Baral 2001), a visit in lowland Nepal (Inskipp and Inskipp 2001), Inaruwa of eastern Nepal (Giri and Baral 2001), Koshi Tappu wildlife reserve (Baral et al. 2002), Sukla Phanta wildlife reserve and Nawalparasi forest (Giri and G.C. 2002), Rampur valley (Gautam and Baral 2004) illustrated that both Gyps vultures have been declining drastically throughout Nepal. This decline is along the same magnitude as those observed in Pakistan (Baral et al. 2003).

Oaks et al. (2004) concluded that residues of veterinary drug 'Diclofenac' are responsible for the WRV declines in the Indian Sub-continent. Various factors, including poisoning and the use of pesticides, reduction in food availability and nesting habitat, abnormally high rates of nesting failure, adult/ juvenile/nestling mortality, diseases, nest predators, hunting, environmental contamination, calcium deficiency, aircraft strikes, and electric lines shock have been reported as possible causes for high Gyps vulture mortality and subsequent population decline (Birdlife International 2000, BirdLife International 2006). Some of these problems may have also been found to occur in Nawalparasi district.

In the recent years, the international, regional and national conservation bodies have expressed crucial concern over the widespread and rapid decline of Gyps vulture. Much stress has been imposed on the identification and/or location of the remaining breeding colonies as well as population of each vulture species as quickly as possible (BirdLife International 2006). Based on important breeding population of WRV, forests of Nawalparasi are declared as Important Bird Area by BirdLife International and Bird Conservation Nepal (Baral and Inskipp 2005). There is still much work to be done to prevent the extinction of greatly affected two species of vulture in Nepal. No extensive vulture studies, except short thoroughfare visits, have previously been conducted in Nawalparasi district of Nepal to asses vulture population dynamics and ecology. In view of these circumstances, a Gyps vulture monitoring was conducted in west of Daunne hill of Nawalparasi district during the breeding season in 2005. The objectives of this study were to identify and monitor Gyps vulture nest localities and behavior, and to understand the local peoples' perceptions about Gyps vulture. The understandings of this study are expected to prove a cornerstone for future conservation, research and long term survival of these magnificent lords of the sky. 


\section{Materials and methods}

\section{Study Area}

Nawalparasi district $\left(27^{\circ} 21^{\prime}-27^{\circ} 47^{\prime} \mathrm{N}\right.$ and $83^{\circ} 36^{\prime}$ $84^{\circ} 35^{\prime} \mathrm{E}$ ) lies in the southern central part of Nepal (Fig 1). Topographically, the district divided in to three regions: Mahabharat hills, Churia hills and the Terai (lowland plain). A ridge of Daunne hills has divided the district into two separate plain area viz Bhitrimadesh in the east and Terai in the west. The study was conducted in the lowland western part of Nawalparasi district i.e. west of Daunne hill and covered the area of Makar, Panchanagar, Ramnagar, Sunwal and Amrout Village Development Committees.

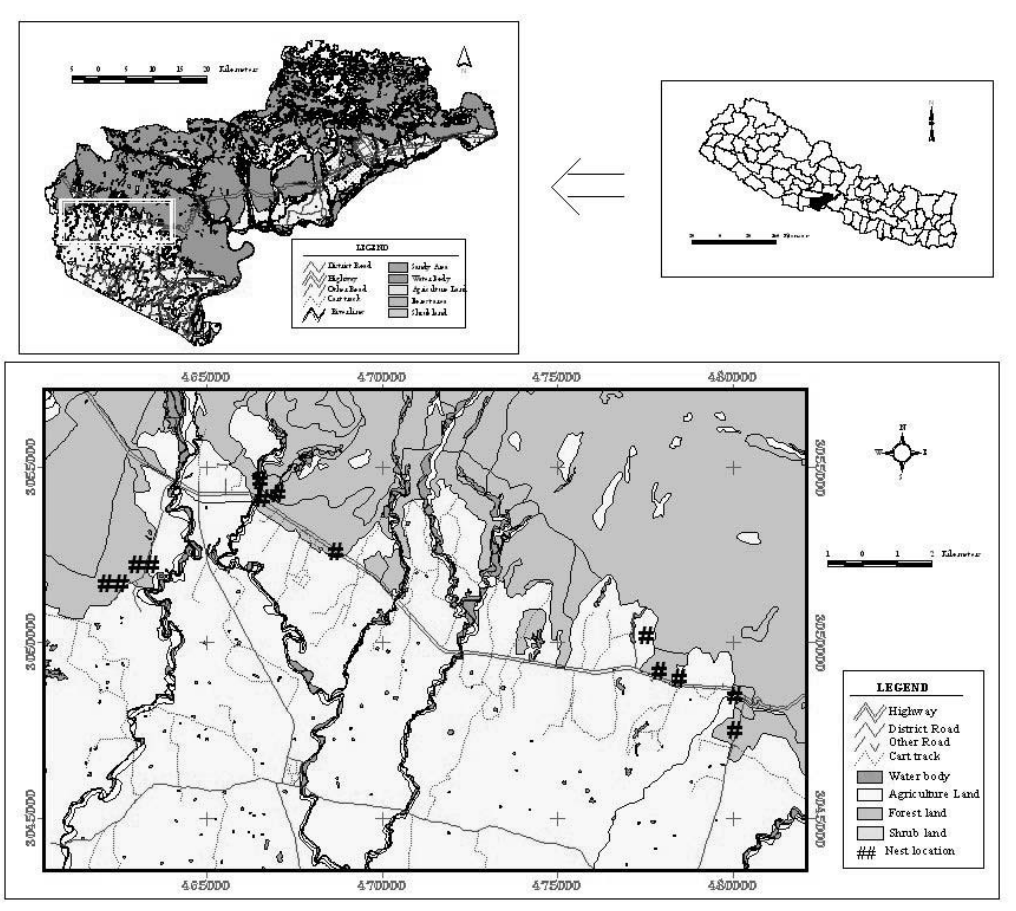

\section{Methodology}

Potential Gyps vultures' nest locations were identified using existing networks of roads and foot/trails from February 25 to March 1, 2005 as well as using secondary information. Postupalsky (1974) criterion was followed for assessing the reproductive success of Gyps vulture. After locating the potential nest colony, nest monitoring and nest activity were recorded from ground level once weekly from March 2 to June 8,2005 . Vulture nests were mostly observed from $6.00 \mathrm{am}$ to $11.00 \mathrm{pm}$ using $20 * 20 \mathrm{CF}$ Nikon Binoculars. All observed nests were recorded and marked using a hand held Global Position System (12XL Navigator Garmin). Each vulture's nest was given the separate number to avoid confusion among nests. Other information i.e. nesting tree species, active and abandoned (non active) nest, nest location in the tree, nesting vulture species, fresh chicks activity and sign of illness (neck drooping of vulture), were also recorded. A sample questionnaire survey was carried out through randomly selected households in the vicinity of vulture colonies to understand inhabitants' perception about vulture population, carcass disposal practices, livestock holdings and veterinary practice, pesticide and fertilizer use and forest resource use. Information on locally practiced pesticides and veterinary drugs was also collected through informal talk with shopkeepers and

Fig. 1: Location of study area.

The district experiences tropical, subtropical and mild temperate types of climate. May and June are the hottest months and December and February are coldest months. The annual rainfall is $150 \mathrm{~mm} /$ year (MFSC 1995). The elevation ranges from 91 to1936 meters above the mean sea level (DDC, 2006). According to the altitudinal variation the average maximum temperature is 28.9 Degree Celsius. A total of 5,62,088 inhabitants are residing in the district (CBS 2002).

The dominant forest vegetation species commonly found in the district are Shorea robusta, Terminalia tomentosa, Dalbergia sissoo, Bombax ceiba, Syzigium cumini, Terminalia chebula, Terminalia belerica etc. Permanent river and seasonal streams drain out from north to the south (DDC 2006). government officials. Study area map was prepared using topographical map of 1:25000 scales (HMG/ N Survey Department 1996) and using GPS field data.

\section{Results and discussion}

\section{Location and distribution of nest}

Vultures were found to be more abundant in the west compared to the east of Nepal (Inskipp and Inskipp 2001) and still hold some population of both WRV and SBV (Baral et al. 2002a). This study has explored the forty-eight numbers of Gyps vulture's nests that were found widely distributed in the study area. Out of the 48 nests; 5, 11, 3, 6, 8, and 15 nests were found in Bardghat, Chisapani, Badera, Sunwal, Hadahiya and Basahiya colonies, respectively (Fig 2). Out of 48 nests, 18 were found active and 30 were found 


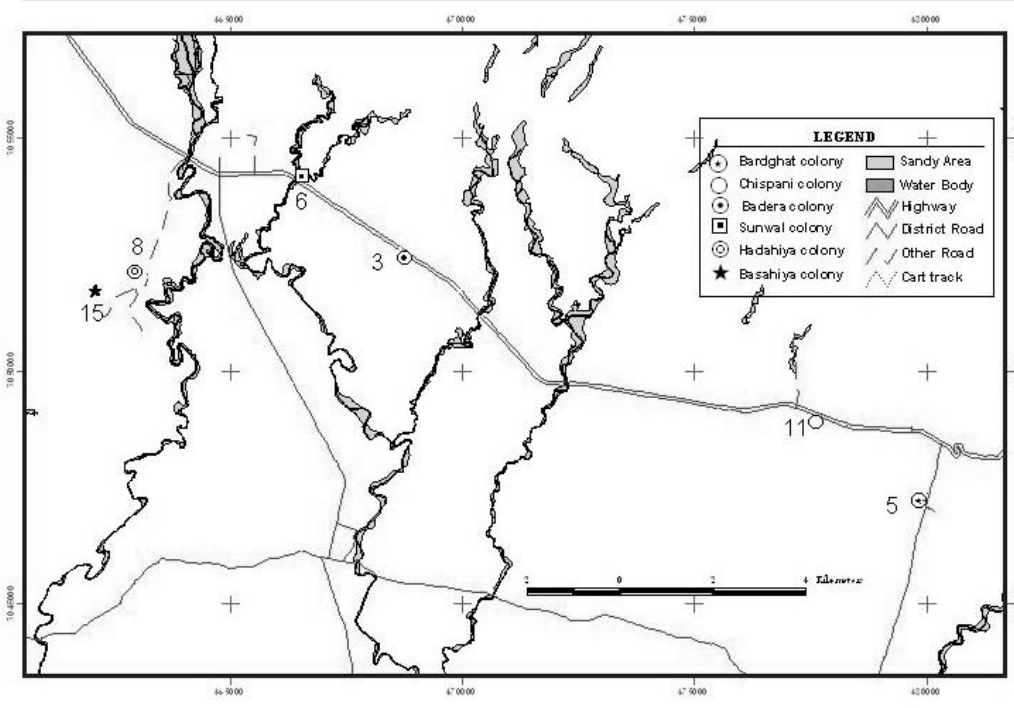

Fig 2: Distribution of minimum number of Gyps vulture nest in the study areas.

abandoned. Among the 18 active nests, 6 nests belonged to SBV and 12 nests belonged to WRV (Table 2). This study explored six nests of SBV in western Nawalparasi that was a surprising and unexpected result amid continuous vulture decline circumstance.

The abundance of vultures in this area can be accounted partly due to the availability of food (floating carcasses) along the approximately 75 Kilometer long watershed and edges of Narayani River and large plain area of Terai and Bhitrimadesh, and partly to the availability of suitable habitats for nesting, roosting and perching.

\section{Nest abandonment}

About 63\% nest abandonment was observed in the study area (Table 2) though no clear causes have been traced for the high rate of abandonment. The time of nest desertion cannot be clearly explained because of late starts of monitoring activities. The high rate of nest abandonment could be due to the heavy strong wind that blew down some portion of nest during egg hatching, the change of old nesting colony by vulture its self, high number of frustration nest, high mortality rate of breeding vulture during nest building and prior or during egg lying, failure of egg during incubation and nestling mortality. The nest position and nest size on tree showed that some of the nests were being used for more than 3 years. Villagers around vulture colony also confirmed this assessment. The vulture might have shifted and built the nest colony in nearby areas. Unfortunately, these probable areas could not be scanned thoroughly because of adverse security condition inside the forest at that time.

\section{Nestling success and nest deserted time of fledgling}

The earlier researchers reported $28 \%$ to $59 \%$ breeding success of $W R V$ in different parts of country (Giri and Baral 2001, Gautam and Baral 2004). During the observation, entire eighteen active nests were observed with chicks and those chicks fledged successfully in May and June. This study explicitly concludes that nestling success was found to be 100\% same as the Myagdi and Syangja colonies in Rampur valley (Gautam and Baral 2004). Literatures and previous studies have not reported such high number of SBV nests (=6) and fledged chick successfully till date in Nepal. This result indicated that this area is listed as one of the major potential SBV's site in Nepal. All parameters (viz. nest building activity prior to egg laying, egg laying and incubation, chick brooding and nestling period) of the breeding process of this study cannot be compared to other studies because this study maintained the data only after hatchlings completed since February 25, 2005.

Table 2: Total, Active, Abandoned and Successful nest

\begin{tabular}{|c|c|c|c|c|c|c|}
\hline \multirow{2}{*}{ S.N. } & \multirow{2}{*}{ Colony } & \multirow{2}{*}{ Total nests } & \multicolumn{2}{|c|}{ Active } & \multirow{2}{*}{ Abandoned } & \multirow{2}{*}{$\begin{array}{l}\text { Nestling } \\
\text { Success }\end{array}$} \\
\hline & & & WRV & SBV & & \\
\hline 1 & Bardghat & 5 & 2 & - & 3 & 2 \\
\hline 2 & Chisapani & 11 & 1 & 1 & 9 & 2 \\
\hline 3 & Badera & 3 & 1 & - & 2 & 1 \\
\hline 4 & Sunwal & 6 & - & - & 6 & - \\
\hline 5 & Hadhiya & 8 & 2 & 2 & 4 & 4 \\
\hline \multirow[t]{2}{*}{6} & Basahiya & 15 & 6 & 3 & 6 & 9 \\
\hline & Total & 48 & 12 & 6 & 30 & 18 \\
\hline
\end{tabular}


Nest deserting period of fledgling were found to vary moderately. In Hadahiya and Basahiya colonies, 7 fledglings were found to desert their nest in between May 23 to 30; and remaining 6 fledglings in between May 30 to June 5, 2005. While in the Bardghat, Chisapani and Badera colonies, 3 and 2 fledglings were found to desert in between May 11-18 and May 18-5, 2005 respectively.

\section{Chick behavior and parental care}

Until the chick reached the fledgling stage, at least one of the parent's vultures was regularly found to care the chick sitting on tree. The parents showed little activities in the early morning however, the late morning witnessed the frequent activities from those parents like standing, sitting, perching, preening and flying out of and to the nest, and sometime lining of the nests. The parents were sometimes found brooding the chick in the nest. When the chick became capable of standing and playing, the parent either stood on the nest or perched on the nearby branch to attend the chick. The chick stood and played with their parents in the nest. By the end of April, most of chicks were seen to reach the fledgling stage. The fledglings were frequently seen preening, standing and sitting on the branch and top of the tree, and shaking the tree they stood on was the most common and frequent activity during nest visiting time.

\section{Nesting tree species and nest height}

Vulture normally prefers nesting site at the edge of forest, open grassland with scattered trees, or in Bombax ceiba and lightly wooded old forest. Generally, WRV nest were found in colonies in treetops as well as rocky cliff at 2-10 meters high. However, SBV nest only reported in trees usually large ones, at a height of 7-14 meter (BirdLife International 2006). The Bombax ceiba is found to be the most commonly used tree species to built nest. Besides this, both Gyps vulture are known to nest in a variety of trees viz Shores robusta, Ficus religiosa, F. bengalensis, Albizzia species, Mangifera indica, Tamarindus indica, Dalbergia sissoo, Azadirachta indica, Eugenia species, Terminalia arjuna (BirdLife International 2006 Grimmett et al. 2000 and Ali and Ripley 1987). In Nawalparasi, Gyps vulture nests were reported on branches and trees tops in all colonies. More than $96 \%$ of vulture nests were found to locate on Terminalia tomentosa and 4\% on Shorea robusta. It is believed that Gyps vultures prefer Terminalia species because of easiness to break small leafy twigs tugging at it with bill, assisted by vigorous wing flapping to build the nest (Ali and Ripley 1968).

The maximum nest height was found at 45 meter on Terminalia tree and the lowest at 16 meter on Shorea tree from the ground level and found abandoned. The average height of nest on the tree was found to be 31.5 meter. The chick fledged successfully from the highest active nest was noted at 37 meter in Hadahiya colony. On the basis of the available literatures and research reports, this nest height measured at this study could be the highest nest record in Nepal.

\section{Neck dropping behaviour and reported dead vulture}

The neck drooping of both Gyps vulture was observed from the beginning of study till June. Through 14 times visit, on an average 5 neck dropper's vultures were noted from the six colonies as shown in figure 3. Neck dropping was also noted in breeding vulture. Abnormally high rate of head (neck) dropping in Gyps species are reported in Nepal and the populations of WRV have declined catastrophically in lowland Nepal (Baral et al. 2004).

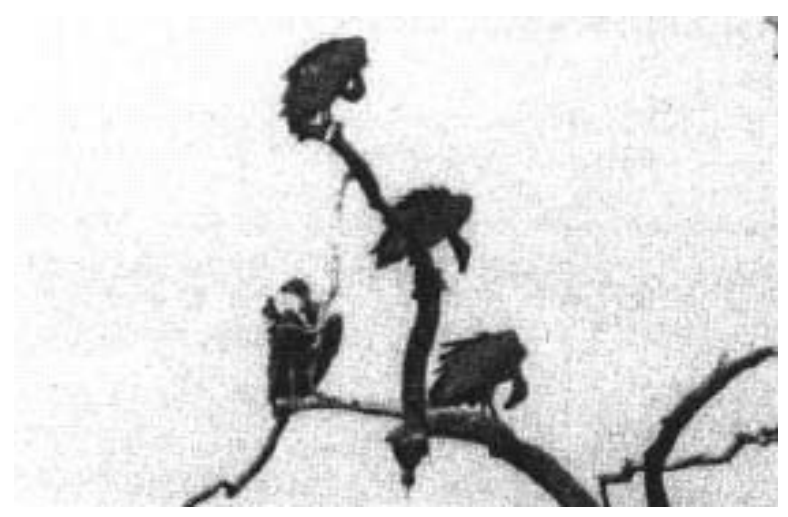

Fig. 3: Indian white-backed vultures showing neck drooping syndrome adopted from Cunningham et.al. 2003.

Prakash (1999) reported that once a vulture was seen to be sick, it invariably died within approximately 30 days of exhibiting sign of neck drooping syndrome. Sick birds continue to feed and fly, but both the degree of lethargy and the periods of neck drooping behavior progressively increase. If this annual trend continues, we cannot imagine the existence of this lord of the sky. Neck dropping to some extent may be a normal behavior in Nepal (Giri and Baral 2001). Some of the wild population of the Gyps vulture in west of Narayani river might have increased immunity power to this syndrome. All together five WRV and one SBV with rotting body with spreading feathers 
were noted in different locations. This study could not collect fresh vulture specimen to perform postmortem and hence it could not explicitly furnish the causes of head dropping and the neck droppers' conditions and causes of death. It is presumed that breeding Gyps vulture with chick did not die in the time of study because of hundred percent nestling successes. Reported dead vultures might be sub adult and immature ones.

\section{Logging concession and its effect on vulture habitat}

About one decade ago, Bombax ceiba - the main roosting and nesting tree species of vultures, was heavily logged from the cultivated area. At that time, more than 70 vultures were regularly seen on roosting in one Bombax tree in Bardghat area (pers comm. Indra Prasad Sapkota). Logging concession seriously limits nesting habitat of vulture that would be negative consequences on breeding success (Gautam and Baral 2004). Recognizing the negative impact of logging on vulture habitat, the government of Nepal (GoN) declared to ban the logging concession of Bombax ceiba, Terminalia arjuna, Shorea robusta, Adina cordifolia, Acacia catechu and Michelia champaca on February 2, 1992. This provision was paralyzed and resulted in continuous destruction of vulture habitats (preferred tree species) even after the enactment of Forest Regulation (1993). Birders, naturalist and government officials of Nepal seriously raised this issue; the GoN again decided to ban the logging of Bombax tree but not Terminalia on September 1998. Unfortunately, the GoN relaxed the prohibition of Bombax ceiba logging concession since November 5, 2007 and this has resulted in the heavy destruction of vulture roosting and nesting habitat.

The concerned authorities that grants logging concessions should at least confirm whether the trees to be logged are being used for vulture's roosting and/or nesting. There is an earnest need to appeal GoN and concerned bodies to make provisions to ban the Terminalia and Bombax species logging concession, if not at least ban logging of the nesting and roosting trees immediately. Unless the interventions to safeguard the vulture habitats are implemented forthwith the existence of the vulture is in great jeopardy.

\section{Social response}

A total of 40 individuals ( 2 female and 38 male and aged 21 to 60 years) were interviewed and found literate, being involved in agriculture in the study area. Sixty percent of the respondents had migrated from mountain districts and other parts of the same district; and the rest (40\%) were local inhabitants. The influx of people to this area started during 1960s after successful malaria eradication program. Other cause of migration to these areas perhaps might be the lack of fertile lands in hilly and mountains districts. The people in the area are heavily depended on forest resources to fulfill the basic needs for their livelihoods. This creates high pressure on autonomous vulture habitat. Basic needs of local people should be addressed through other conservation endeavors to ensure the sustainability of resources and vulture habitat.

\section{Livestock holdings, carcass disposal practice and Veterinary treatment}

A total of 356 livestock head were reported to be reared by the respondents. The average livestock unit $(\mathrm{LU})$ was about 3.83 per household in the study area. Thirty-two livestock were reported to have died during the 5-year period in the study area. Seventyfive percent of the total death was due to diseases, $12.5 \%$ due to old age, and $12.5 \%$ due to accidents. One third of the diseased livestock was reported to die after treatment. When domestic animals die, 70\% of the households' throw the carcasses in open fields (such as stream bank, forest area and/or communal land), $20 \%$ of them buried and $10 \%$ of them call skin tanner. Generally, it was reported that when livestock die due to diseases were always buried to prevent the potential spread of disease to their remaining livestock and human but not certainly to prevent vultures' death due to Diclofenac poisoning. They preferred to throw out carcass in open field in case of natural death of animals. This local practice was reported favorable to the vulture welfare.

Veterinary facilities were found available within 3 kilometer distance from the settlement. Out of 31 Agrovet shops in the district, 18 are located in the study area (DDC 2006). Seven of eighteen shops provided the veterinary drugs and pesticides the name upon the request of researcher but they refused to provide the sold amount. Other shops denied providing any information regarding this. Eighty percent of the respondents called veterinarian (Doctor and JTA) to treat the livestock illness. Commonly available and practiced veterinary drugs in the local market are presented in Table 4. 
Besides other veterinary drug, Diclofenac is the easily available medicine to treat the livestock in the study area (pers. comm. Shovakar Gyawali). Almost all shopkeepers sell the Diclofenac as per requirement of the customers though, they were unaware about the side effects of the Diclofenac to the vulture. The wild WRV might have exposed to Diclofenac through contaminated water sources but the very low water concentration is unlikely to cause toxicity (Okas et al. 2004). The actual quantity consumed and/or injected to the animal could not be made available.

\section{Use of fertilizer and pesticides}

Both synthetic (Urea, Potash and DAP) and organic fertilizers (compost, cattle dung) as well as chemical pesticides were found use by farmers in agriculture cultivation. Majority of the respondents (65\%) used both organic and synthetic fertilizers as per their personal judgment. Small proportion $(10 \%)$ of the respondents used only organic manure in their farms; while $20 \%$ respondents used only synthetic fertilizer in their farm annually.

High proportion $(70 \%)$ of respondents were frequently found using pesticides in their agricultural land to protect the crop from the harmful insects/ pests. Out of 306 types of pesticides (Nepal's Pesticides Act 1991), 25 are commonly used in the study area and 12 of them are prohibited by this Act. Commonly used pesticides in the study area are given in Table 4. Some of prohibited pesticides viz. BHC and DDT are reported to be used in the study area. Use of pesticides like Forate, Malathion and Fenvalerate has been increasing enormously (Giri and Baral 2001). Actual quantity of pesticides being used/ consumed in the study area could not be obtained because of reluctance of shopkeepers to provide the actual data on their sales. Hence, this study could not reach the conclusion on this aspect. Respondents were found unaware of the prohibited pesticides and their side effects to the living beings.

\section{Conservation Attitudes}

Conservation attitude of the people was assessed by presenting 18 dichotomous (agree or disagree) statements to line up the people's opinion to conserve the Gyps vulture. The overwhelming majority of the respondents demonstrated favorable attitude towards vulture conservation. Hundred percent respondents showed willingness and interest to contribute financially (ranging from Rs.1 to 50 per year) to support vultures conservation activities such as habitat conservation, extension education, establishment of conservation NGOs and awareness program. All respondents were found to support of community forest. Majority of respondent (55\%) affirmed that the veterinary drugs, pesticides and chemical fertilizer as the cause of vulture decline. Eighty five percent of them also expressed serious concern over vulture conservation for our future generation, religious purposes, and stability of the ecosystem.

\section{Conclusion}

Encouragingly, the highest number (48) and widely distributed Gyps vultures' nests were reported in the study area. Entire active nests (18) were observed with chicks fledged successfully. This study explicitly concluded that western part of Nawalparasi district, particularly west of Damne hills, is found to be one of the good strongholds of Gyps vulture. If any actions to conserve the vulture habitat are not taken on time, the existence of the vulture will be at stake and we will have to face irreparable loss.

Further studies on Gyps vulture focusing on breeding status, nest distribution and nest desertion, head droppings, is imperative to lineup other unidentified and unexplored information in this area. Conservation awareness program among the local inhabitants and local school children focusing vulture present status, threats and its role in the environment

Table 4: Commonly used pesticides and veterinary drugs in the study area.

\begin{tabular}{clclcl}
\hline S.N. & Veterinary drugs & S.N. & \multicolumn{2}{c}{ Pesticides } \\
\hline 1 & Diclofenac & 1 & Indosulfan & 2 & Indosolphan \\
2 & Gentamycine & 3 & Methyle parathion & 4 & Dichlorvus \\
3 & Oxytetracycline & 5 & Segar & 6 & Cypermetheran \\
4 & Ampillicine & 7 & Malathion & 8 & Micropower \\
5 & Vita B complex +Vitamins +Mera & 9 & Zinc phosphide & 10 & Aluminium phosphide \\
6 & Introflaxacin & 11 & Cypermethrine & 12 & Mencozeb \\
7 & Anthalmantic & 13 & BHC & & \\
Source: District Agriculture Service Office and District Livestock Office, Nawalparasi & &
\end{tabular}

Source: District Agriculture Service Office and District Livestock Office, Nawalparasi 
need to be conducted to promote the long term survival of this species at this site.

\section{Acknowledgement}

This study was supported by the Bird Conservation Nepal. I acknowledge the District forest Office Nawalparasi; Livelihood for Forestry Program- Area Office Butwal; The Peregrine Fund-USA; Oriental Bird Club-UK for their cooperation and former article support. My special thanks go to Ms Carol Inskipp for her encouragement and suggestions and document support. Local people of the study area deserve my sincere appreciation for their help and cooperation.

\section{References}

Ali, S. and Ripley, D. 1989. A Pictorial Guide to the Birds of the Indian Subcontinent. Bombay Natural History Society, India.

Ali, S. and Ripley, S.D. 1968. Handbook of the Birds of India and Pakistan. Together with those of Nepal, Sikkim, Bhutan and Ceylon. Vol (I) Divers to Hawks, Oxford University Press.

Baral, N. and Gautam, R. 2007. Why should conservationists go beyond protected areas to safeguard critically endangered vulture? Danphe Vol 16 (1).

Baral, H.S., Giri J.B., Som, G.C., Giri, D., Bindari, B., Subedi, H., Khadka, K. and Baral, H.B. 2002. Study of Vultures in Lowland Nepal. A report submitted to The Royal Society for the Protection of Birds, UK. Unpublished.

Baral, H.S. and Inskipp, C. 2004. The State of Nepal's Bird 2004. Department of National Parks and Wildlife Conservation, Bird Conservation Nepal and IUCN Nepal. Kathmandu.

Baral, H.S. and Inskipp, C. 2005. Important Bird Areas in Nepal: Key Sites for Conservation. Bird Conservation Nepal and BirdLife International, Kathmandu and Cambridge.

Baral, H.S., Giri J.B. and Virani, M.Z. 2004. On the decline of oriental White backed vultures Gyps Bengalensis in Lowland Nepal. In Chancellor R.D. $\approx$ \&.U Meyburg (ed) Raptor Worldwide, WWGB/ MME, 215-219.

Baral, H.S., Giri, J.B., Poudel, N., Upadhyay, G.P., Watson, R. and Virani, M. 2003. Summary of results from the Himalayan Kingdom of Nepal for the field seasons 2000/2001, 2001/2002, and 2002/2003-(02 Dec 03) Download <http:// www.peregrinefund.org/archived_conserve.asp? mode $=$ view\&ConserveID $=84 \&$ category $=$ Asian $\%$ 20Vulture $\% 20$ Crisis\& conserveid1 $=73>$

Baral, H.S., Poudel, N., Giri, J.B., Waston, R. and Virqani, M. 2002a. Study of Vultures in Lowland Nepal. Final report submitted to The Peregrine Fund, USA. Unpublished.

Baral, H.S. 2006 Vulture conservation in Nepal. In Proceeding of 23rd Warden Seminar 14-16 November 2006 (ed) DNPWC 2006, Annapurna Conservation Area, Pokhara; Department of National Parks and Wildlife Conservation, Nepal.

BirdLife International 2000. Threatened Birds of the World. Barcelona and Cambridge, UK; Lynx Editions and BirdLife International. P:180.

BirdLife International 2001. Threatened Birds of Asia. BirdLife International, Cambridge. 966-980.

BirdLife International 2006. Threatened Birds of the World. IUCN RED list of Birds Http:// www.birdlife.org/action/science/species/ global_species_programme/red_list.html. BirdLife International, Cambridge, UK.

CBS. 2002. Statistical Pocket Book Nepal. Central Bureau of Statistics, Kathmandu, Nepal.

CITES. 2008. Convention on International Trade in Endangered Species of Wild Fauna and Flora Appendices I, II and III valid from 1 July 2008, Geneva, Switzerland downloaded from http:// www.cites.org on 12 July 2008.

Cunningham, A.A., Prakash, V., Pain D., Ghalsasi, G.R., Wells, G.A.H., Koltea, G.N, Nighota, P., Goudaf, M.S., Kshirsagal, S. and Rahmani, A. 2003. Indian vultures: victims of an infectious disease epidemic? Animal Conservation (6) I 89-1 97.

DDC. 2006. District Profile of Nawalparasi District, District Development Committee, Nawalparasi, Nepal.

Fleming, R.L.Sr., Fleming, R.L.Jr. and Bangdel, L.J. 1976. Birds of Nepal. Nature Himalayas. Kathmandu.

Gautam, R. and Baral, N. (2002). Status of White rumped vulture Gyps bengalensis in Rampur valley, Nepal. OBC Bulletin No. 36:46-48. 
Gautam, R. and Baral, N. 2004. Studies on White Rumped Vulture Gyps bengalensis from Ecological and Socio-economic Perspectives in Rampur Valley, Nepal. Final report submitted to The Oriental Bird Club, UK.

Gilbert, M. 2004. Veterinary drugs responsible for Asian vulture decline. World Birdwatch. March 2004 $26.1 \mathrm{pp}: 12-13$.

Giri, J. and Baral, H.S. 2001. Study of Vultures in Lowland Nepal. Final report submitted to The Peregrine Fund, USA.

Giri, J.B. 1996. A study of Birds' Behaviour in Gokarna Sanitary Landfill Site. M.Sc. Thesis. Tribhuvan University, Kathmandu, Unpublished.

Giri, J.B. and Som, G.C. 2002. Study of Vultures in Far-Western Lowland of Nepal. Report submitted to The Oriental Bird Club, UK.

Grimmet, R., Inskipp, C. and Inskipp T. 2000. Birds of Nepal. New Delhi, India.

Grimmett, R., Inskipp C. and Inskipp T. 1998. Birds of the Indian Subcontinent. Christopher Helm, London.

Inskipp, C. and Inskipp, T. P. 2001. A re-visit to Nepal's lowland protected areas. Danphe 10:4-7.
Inskipp, C. 1989. Nepal's Forest Birds: Their Status and Conservation. Second Edition, Christopher Helm, London.

Inskipp, C. and Inskipp T.P. 1991 A Guide to the Birds of Nepal. Second edition. Christopher Helm, London.

MFSC. 1995. Operational Forest Management Plan of Nawalparasi District, Kathmandu, Nepal.

Oaks, J.L., Gilbert, M., Virani, M.Z., Waston R.T., Meteyer, C.U., Rideout, B.A., Shivaprasad, H.L., Ahmed, S., Chaudhry, M.J.I., Ashrad, M., Mahmood, S., Ali, A. and Khan, A.A. 2004. Diclofenac residue as the cause of vulture population decline in Pakistan. Nature Vol 427:(12), 630-633.

Panthi, K. 1996. Birds Diversity in Gokarna. M.Sc. Thesis. Tribhuvan University, Kathmandu, Unpublished.

Postupalsky, S. 1974. Raptor reproductive success: some problems with methods, Criteria and Terminology. In Hamerstrom et.al. Proceeding of the conference on Raptor Conservation Techniques for Collins, Co.21-30. 